\title{
Back to the Future: Rediscovering the Non-Economic Role, Value and Scope of Labour Law and Collective Labour Institutions in a Changing World
}

DOI:

http://dx.doi.org/10.5040/9781509921584.ch-006

\section{Document Version \\ Accepted author manuscript}

Link to publication record in Manchester Research Explorer

Citation for published version (APA):

Vergis, F. (2019). Back to the Future: Rediscovering the Non-Economic Role, Value and Scope of Labour Law and Collective Labour Institutions in a Changing World. In A. Blackham, M. Kullmann, \& A. Zbyszewska (Eds.), Theorising Labour Law in a Changing World: Towards Inclusive Labour Law (pp. 81-106). Hart Publishing . https://doi.org/10.5040/9781509921584.ch-006

\section{Published in:}

Theorising Labour Law in a Changing World

\section{Citing this paper}

Please note that where the full-text provided on Manchester Research Explorer is the Author Accepted Manuscript or Proof version this may differ from the final Published version. If citing, it is advised that you check and use the publisher's definitive version.

\section{General rights}

Copyright and moral rights for the publications made accessible in the Research Explorer are retained by the authors and/or other copyright owners and it is a condition of accessing publications that users recognise and abide by the legal requirements associated with these rights.

\section{Takedown policy}

If you believe that this document breaches copyright please refer to the University of Manchester's Takedown Procedures [http://man.ac.uk/04Y6Bo] or contact uml.scholarlycommunications@manchester.ac.uk providing relevant details, so we can investigate your claim.

\section{OPEN ACCESS}




\title{
Back to the future: Rediscovering the non-economic role, value and scope of labour law and collective labour institutions in a changing world
}

\author{
FOTIS VERGIS*
}

\section{Introduction}

'All this has happened before; and all this will happen again'. It is rare for a historian, a biblical $^{1}$ or Marxist ${ }^{2}$ scholar, or simply a fan of modern fairy-tales ${ }^{3}$ or good contemporary sci-fi to converge on a statement they all can agree on. However, the value of drawing lessons from our socio-political past to understand and address the seemingly novel challenges of the present should not escape our attention. As we observe, often bewildered, the rapidness with which contemporary social, economic, political and technological developments unfold, we barely have time to grasp the full details of the changes they bring about. The frantic pace makes it appear as if our traditional analytical and theoretic constants - our fundamental assumptions - are inadequate to grasp the new reality and in dire need of revision. In a world economy that is, in developed economies, post-Fordist and increasingly deregulated for the sake of flexibility and which, in developing countries, almost mirrors the appalling conditions of early Fordist industrialised production, traditional conceptions of labour law and its mechanisms are increasingly perceived as ill-equipped to provide a coherent framework for labour protection. Regulatory concepts and institutional structures, embedded in post-World War II western social regulation, reflect not only bygone production models but also the balance of political and market forces' power as it existed at a fixed point in time that now seems ancient.

\footnotetext{
* Lecturer in Law, School of Law, The University of Manchester.

${ }^{1}$ Ecclesiastes 1:9.

${ }^{2}$ K Marx, The Eighteenth Brumaire of Louis Bonaparte (1852).

${ }^{3}$ The phrase is the opening line of the 1953 animated film 'Peter Pan'.
} 
However, reinventing the wheel might not be necessary. Perhaps all we have to do is take a breath, go back and remember the lessons of the past on how and to what end labour law and its collective labour institutions first came about. This chapter proposes going back to the historical and conceptual roots of collective labour organisation, to recall the value of the concept of labour itself, and the objectives of the mechanisms that emerged to ensure its protection from coercion and abuse of power.

It is certainly possible to rethink the role and function of collective mechanisms within a market economy, and suggest that balance is possible, by placing our discussion in the dominant narrative, which focuses on the economic aspect and effect of labour institutions, and adopting a similarly retrospective rationale. In that case, our dive into the past would entail reconnecting with institutional and neoclassical economic theory to reveal the fallacies of contemporary dominant economic theses, influenced by neoliberal musings, that display an aversion to labour rights and collective labour institutions, as they consider them 'externalities', rather than inherent features of the market and the economic system as a whole. However, such a discussion would exceed the scope and space this chapter can afford.

Similar conclusions to such an economic analysis can be reached by moving away from the economic rationale that has dominated discourse to date. This chapter seeks to reconnect the concept of 'labour', the fundamental core of the protective nexus of labour law, to its normative content, as an element of identity and social recognition. By examining the political history and the theoretical basis of the emergence of collective labour institutions, the chapter discusses the role of collective labour organisation and action as an inherent catalyst for market democratisation and, therefore, as a prerequisite for a functional liberal democracy. By looking into the historical roots of labour law, collective autonomy and selfdetermination - as opposed to top-down regulation - will be shown to be the foundations of fundamental labour law concepts and ensuing rights. Furthermore, building upon ideas expressed by Polanyi and Sinzheimer, among others, solidaristic structures of collective expression of voice are demonstrated to be integral in embedding the economy in its sociopolitical context, inducing structural systemic democratisation, and promoting an ethos of participation.

\section{Collective Labour Law and the Challenges of the Modern Global Economy}

The non-economic value of labour law and collective labour processes has almost receded into obscurity in the judicial and political understanding and approach of recent years. In fact, reference to the 'social' nature of labour rights is often used to highlight the suggested discrepancy between social and economic rights, and perpetuate the perception that collective labour institutions are almost by definition directly at odds with economic rights, as interpreted by reference to established economic rationales. In that respect, collective labour institutions are merely tolerated insofar as the primacy of economic freedoms and interests is not found to be at risk. 
This understanding of collective labour law, however, is hardly definitive. Rather, it merely reflects a very particular strand of thought rooted in neoclassical economic theory ${ }^{4}$. Such a narrow economocentric approach, based on a very specific understanding of economic theory, essentially allows analyses to ignore the constitutive role of collective institutions and the inherent symbiotic relationship of institutional mechanisms and their societal and sociopolitical context ${ }^{5}$.

Further, this predominantly economic approach conveniently obscures the dynamic essence of collective labour institutions. It presents them as a more or less fixed, albeit not entirely desirable, fixture of an economic system that is in itself largely a given constant judged against the aspired golden standard of the rational, competitive free market economy. What is conveniently downplayed, if not entirely forgotten, is that labour law and its institutions might be a fixture of the modern capitalist system, but they are not a conditio sine qua non of the aspired free market standard of neoclassical theory, nor were they ever a given. On the contrary, they were forged in the conflicts ${ }^{6}$ that followed the early industrialisation of labour $^{7}$ and the emerging need to rebalance the worker/employer relationship within a system of organised mass production.

Labour law systems and relevant legal conceptions across Western Europe, now seen as the 'traditional' rigid systemic fixtures that ought to be reconsidered as antithetical to market flexibility, emerged as a response to challenges brought about by the full adoption of the Fordist model of mass production, its ensuing narrow specialisation of labour ${ }^{8}$ and the reorganisation of businesses into the model of the hierarchical workplace, usually as a centralised, largely self-contained unit ${ }^{9}$. The resulting traditional institutional paradigm took the form of a labour market regulatory structure constructed upon the twin pillars of autonomous regulation through collective bargaining and of the welfare state ${ }^{10}$. The economic rationale for sacrificing some freedom from regulatory intervention in the market and slightly retreating from the individualistic ideal of the worker as a rational economic actor in favour of more collective processes was to ensure a standard of living for workers

\footnotetext{
${ }^{4}$ See, inter alia, GR Boyer and RS Smith, 'The Development of the Neoclassical Tradition in Labor Economics' (2001) 54 Industrial \& Labour Relations Review 199; see also W Lord Wedderburn, Employment Rights in Britain and Europe (London, Lawrence and Wishart, 1991) 204 discussing Thatcherite interpretation of Hayek anti-union sentiments.

${ }^{5}$ See N MacCormick, Institutions of Law: An Essay in Legal Theory (Oxford, Oxford University Press, 2007) 171-240.

${ }^{6}$ T Van den Bergh, The Trade Unions - What Are They? (Oxford, Pergamon Press, 1970) 3-4. Van den Bergh provides a series of accounts of the history of industrial conflicts in the UK labour market, which evolved alongside the industrialised capitalist economy.

${ }^{7}$ See S Deakin and F Wilkinson, The Law of the Labour Market: Industrialization, Employment, and Legal Evolution (Oxford, Oxford University Press, 2005) 11-18, 34-35, 108 (also, see 4-18, 00-05); BE Kaufman, 'Labor Law and Employment Regulation: Neoclassical and Institutional Perspectives' in D-S Kenneth, S Harris and O Lobel (eds), Labor and Employment Law and Economics (Cheltenham, Edward Elgar, 2009) 3.

${ }^{8}$ A Supiot, Beyond Employment: Changes in Work and the Future of Labour Law in Europe (Oxford, Oxford University Press, 2005) 1.

${ }^{9}$ ibid.

${ }^{10}$ A Lipietz, 'Post-Fordism and Democracy' in A Amin (ed), Post-Fordism Reader (Oxford, Blackwell, 1994) 342. See also G Esping-Andersen, The Three Worlds of Welfare Capitalism (Cambridge, Polity Press, 1990).
} 
that would induce consumption, completing and perpetuating a stable mass production-mass consumption cycle ${ }^{11}$.

However, the ground upon which the institutional apparatus of labour law was built has since shifted, as the world moved towards today's meta post-Fordist ${ }^{12}$ globalised economy. This new mass-consumption driven paradigm is founded upon transnational, integrally connected markets which are based on free movement of capital, production, and services and focused on unrestrained competition ${ }^{13}$.

This shift has been followed by the incorporation into theory and policy of a combination of neoclassical, post-Fordist and post-modern ${ }^{14}$ market characteristics, such as an individualistic ethos and an aversion to trade unionism and labour market self-regulation through collective labour law mechanisms ${ }^{15}$. The increasing emphasis on the globalised free market ideal, devoid of any regulatory intervention (including on the basis of collective autonomy) that would impede competitiveness and set upon further promoting 'flexibility' of labour forms and relations, ultimately reflects a neoclassical, and increasingly neoliberal ${ }^{16}$, evolution ${ }^{17}$ of capitalist market economies on a global scale. The rapid pace at which this change has unfolded in recent decades has brought with it radical departure ${ }^{18}$ from familiar

\footnotetext{
${ }^{11}$ Lipietz, 'Post-Fordism and Democracy' (n 10).

12 The term 'post-Fordism' is ambiguous and has been used in an attempt to describe many a characteristic of market and production modernization (technologic advance, 'flexible specialiszation', post-industrialism and shift to services, to name a few). Post-Fordism has thus been criticised as a vague and inaccurate concept of convenience. See A Amin, 'Post-Fordism: Models, Fantasies and Phantoms of Transition' in A Amin (ed), PostFordism: A Reader (Oxford, Blackwell, 1994) 1-39; R Munck, 'Labour Dilemmas and Labour Futures’ in R Munck and P Waterman (eds), Labour Worldwide in the Era of Globalization (Oxford, Palgrave MacMillan, 1999) 10. cf K Kumar, From Post-Industrial to Post-Modern Society: New Theories of the Contemporary World (2 edn, Oxford, Blackwell, 2005) 61ff (87-88). It is for this reason that Munck has warned against identifying a clear divide between 'Fordism' and Post-'Fordism' as two supposedly coherent distinct stages of the evolution of capitalist market economy: Munck, 'Labour Dilemmas and Labour Futures' 5; cf K Williams, T Cutler, J Williams and C Haslam, ‘The End of Mass Production?’ (1987) 16 Economy and Society 405, 438.

${ }^{13}$ Munck, 'Labour Dilemmas and Labour Futures' (n 12) 10; R Smith, 'The Convergence/Divergence Debate in Comparative Industrial Relations’ in M Rigby, R Smith and T Lawlor (eds), European Trade Unions: Change and Response (London, Routledge, 1999) 11.

${ }^{14}$ The term alludes to aesthetic, ethical, moral and cultural characteristics, shaped in part by the evolution of economic structures. See, inter alia, D Harvey, The Condition of Postmodernity: An Inquiry into the Origins of Cultural Change (Oxford, Blackwell, 1989). cf $\mathrm{P}$ Anderson, The Origins of Postmodernity (London, Verso, 1998); F Jameson, The Cultural Turn: Selected Writings on the Postmodern, 1983-1998 (London, Verso, 1998); A Callinicos, Against Postmodernism: A Marxist Critique (Cambridge, Polity, 1989). For a fiercer critique see A Sokal and J Bricmont, Fashionable Nonsense: Postmodern Intellectuals' Abuse of Science (New York, Picador, 1998).

${ }^{15}$ M Rustin, 'The Politics of Post-Fordism: Or, The Trouble with 'New Times'” (1989) May-June New Left Review 54, 61-62.

16 According to Rustin, 'Thatcherism may be understood as a strategy of post-Fordism initiated from the perspective of the right': ibid 75. See also D Harvey, A Brief History of Neoliberalism (Oxford, Oxford University Press, 2007) 13-19; C Crouch, The Strange Non-Death of Neoliberalism (Cambridge, Polity Press, 2011).

17 RJ Antonio and A Bonanno, ‘A New Global Capitalism? From “Americanism and Fordism” to “Americanization-Globalization”’ (2000) 41 American Studies 33.

${ }^{18}$ See Supiot, Beyond Employment (n 8) 283, 50.
} 
norms, structures and their certainties ${ }^{19}$, leading Lash and Urry to describe the result as 'disorganised capitalism' ${ }^{20}$.

This paradigm change, therefore, demanded established collective labour institutions to reconnect with their dynamic element, which had always grounded them in socioeconomic and political reality, and had been the power that defined their character since their emergence. It was this element that had allowed such institutions the flexibility to adapt to the changing demands of the evolving market and production system, on the one hand, and the readiness to act as a countervailing force against violent changes that would threaten the interests of workers on the other. Instead of this essential reboot, however, decentralisation and the emphasis on establishment-level labour relations ${ }^{21}$, in conjunction with the advent of flexible and atypical work relations, had a significant impact on the strength and role of trade unions, even in relation to their narrower function as market actors and co-regulators ${ }^{22}$. Perhaps more importantly, trade unions, displaying the instinctive rigidity that established institutions develop in lieu of the more dynamic character of their early days, instead of resisting or reinventing themselves ${ }^{23}$ to better connect with their changing base and its needs, apparently chose to embrace the new ethos and attempt to adapt to contemporary economic rationales of efficiency and productivity as their primary focus ${ }^{24}$, essentially accepting the argument that achieving these aims for the business would trigger the 'trickling down' of benefits for workers. In other words, trade unions essentially conceded to a purely economic understanding of their role.

This retreat to economic pragmatism, however, also inherently includes the adoption of a more conciliatory ethos, that impliedly accepts a commonality of interests between labour and management. This is a stark departure from the conscious understanding of the inherent conflict of interests in the unbalanced power relationship between workers and their employer that had been the foundation of the identity of trade unions as vehicles of collective expression of workers' interests and instruments designed to rebalance the relationship not only through negotiation and conciliation but also coercion. This change in stance has arguably contributed to trade unions losing their 'representational credibility' ${ }^{25}$ in the eyes of individual workers and their position in the collective imagination as actors of not only an economic, but also a social and political, role.

\footnotetext{
19 S Lash and J Urry, The End of Organised Capitalism (Cambridge, Polity, 1987) 312-13. cf F Traxler, 'Collective Bargaining and Industrial Change: A Case of Disorganization? A Comparative Analysis of Eighteen OECD Countries' (1996) 12 European Sociological Review 271, who is critical of the disorganisation thesis as a synonym of a linear, unavoidable (or 'deterministic', at 272) and unitary (at 275) process of convergent deconstruction. However, he does concede to evidence of shifts in perceptions, structures and paradigms, albeit resulting in diversity and multiplicity rather than convergence (at 279-83).

${ }^{20}$ Lash and Urry, The End of Organised Capitalism (n 19).

${ }^{21}$ R Hyman, ‘European Unions: Towards 2000’ (1991) 5 Work, Employment and Society 621, 626-27.

${ }^{22}$ Smith, 'The Convergence/Divergence Debate in Comparative Industrial Relations' (n 13) 11.

${ }^{23}$ Supiot, Beyond Employment (n 8) 50-51.

${ }^{24}$ W Streeck, Social Institutions and Economic Performance: Studies of Industrial Relations in Advanced Capitalist Economies (Londen, Sage, 1992).

${ }^{25}$ R Hyman, 'Trade Unions and the Disaggregation of the Working Class' in M Regini (ed), The Future of Labour Movements (2 edn, London, Sage, 1994) 150.
} 
It could be maintained, then, that a narrow economic understanding of collective labour law as a mainly cooperative institution within the context of advancing the interests of the business, as a supposed all-encompassing unitary whole, has contributed to the 'disaggregation of the working class ${ }^{26}$ into isolated business-related pockets of workers with no sense of commonality, and hence no broader solidarity and interconnection. ${ }^{27}$

However, the ideological dominance of a particular economic theory should not result in us adopting its assumptions as religious dogma, setting aside all other analyses or, indeed, disregarding the reality that led to the emergence of certain institutions. The non-economic objectives and functions of labour law, in general, and collective labour institutions, in particular, are critical and remain topical, regardless of the evolution of market structures.

\section{Collective Labour Law as an Instrument in the Service of Social, Democratic, and Political Values and Objectives}

The 'social' element of labour law has largely provided the core of traditional analyses as well as the popular understanding of the function and utility of labour regulation. Regardless of the form of political or economic mantle under which a human community operates, people are inherently dependent on each other ${ }^{28}$ and on the subsequent social and legal structures that govern human labour and its organisation ${ }^{29}$. This interdependence manifests as the interconnection of the outcomes of each individual's labour to produce the necessary means of subsistence ${ }^{30}$ for all, but it also describes the cooperative element inherent in work and in any labour market as a whole ${ }^{31}$. In that sense, labour, its function and the organisation of its provision and division, have a dual, individual and collective, character, relevant to the basic individual needs of labourers, on the one hand, but also to the fundamental political and social structures of any given society on the other ${ }^{32}$. Therefore, any economic system cannot by itself define, regulate or explain its structures. There will always arise a social impetus to reconnect economic arrangements and conceptions back to considerations that relate to the individual, as well as the collective, element of the society and polity she lives in. Within that context, after all, individuals are identified and defined in their three, inherently coalescent, capacities: as persons, as bourgeois citizens (members of a particular societal configuration

\footnotetext{
${ }^{26}$ ibid $150 \mathrm{ff}$.

27 ibid 151.

${ }^{28}$ See GWF Hegel, Elements of the Philosophy of Right (AW Wood ed, H Nisbet tr, Cambridge, Cambridge University Press, 1991) §183, 221, 189, 227. See also T Kohler, 'Civic Virtue at Work: Unions as Seedbeds of the Civic Virtues’ (1995) 36 Boston College Law Review 279, 295.

${ }^{29}$ NH Smith and J-P Deranty, New Philosophies of Labour: Work and the Social Bond (Leiden, Brill, 2012$) 6$.

${ }^{30}$ Hegel, Elements of the Philosophy of Right (n 28) §182-183, 220-221; Smith and Deranty, New Philosophies of Labour (n 29).

${ }^{31}$ Smith and Deranty, New Philosophies of Labour (n 29).

${ }^{32}$ See, for example, JA McCartin, Labor's Great War: The struggle for Industrial Democracy and the Origins of Modern American Labor Relations, 1912-1921 (Chapel Hill and London, University of North Carolina Press, 1997) 95, where three primary workers' demands are highlighted: those for a rule of law in the workplace, for workers' voice in the determination of working condition, and for claiming workers' rights as citizens through their labour.
} 
and the classes therein), and members of a particular political community, a particular polity $^{33}$.

Workers retain these three capacities, even as labour actors, in their activity within the workplace. The multiple functions of collective labour law structures correspond to considerations that are relevant to each of those, be it individualistic (e.g. economic freedom and interests) or collective (e.g. solidaristic or class-related) in nature. In that respect, trade unions act as hubs of socialisation and democratisation within a market structure, allowing these three properties of individual activity to emerge in the workplace, and their broader social and political effects to be mirrored in that context. Trade unions are as much economic institutions as they are elements of civic society. As such, they reflect and promote communal values, such as cooperation, solidarity and the sense of human interdependence and commonality of interests, as opposed to the individualistic, selfish ethos ${ }^{34}$, the 'atomism ascendant ${ }^{35}$, of neoclassical economic perceptions ${ }^{36}$.

\section{A. Collective Labour Institutions as a Catalyst of Social Re-Embedding of the 'Market Economy'}

It follows that, in Polanyian terms, collective labour institutions can provide an anchor for reembedding the market in its specific social context, coupling economic considerations with their inherent social base.

For Polanyi, the neoclassical idea of a self-calibrating market, that is neutral and can exist outside and beyond social and legal frameworks, is a fallacy. ${ }^{37}$ The market, as socially constructed, is always inherently connected with specific social structures, institutions, and norms, and with specific political choices. ${ }^{38}$ It is impossible to commodify everything, turning the entirety of human behaviour and activity into something that can be objectively explained by the rules of trade or economic rationales.

Human labour, in particular, is for Polanyi a 'fictitious commodity'. It was never intended as something to be 'produced' and 'traded' in a market like any other commodity, thereby following the market's 'natural' laws ${ }^{39}$. It is a human activity that cannot be detached from its multiple functions ${ }^{40}$, including as a catalyst of personal self-awareness and development, as an expression of the worker's very physical, 'moral, psychological and moral' entity ${ }^{41}$ and identity, and as a vehicle of social participation ${ }^{42}$. Therefore, labour cannot be entirely

\footnotetext{
${ }^{33}$ H-C Schmidt am Busch, 'The Legacy of Hegelian Philosophy and the Future of Critical Theory’ in NH Smith and J-P Deranty (eds), New Philosophies of Labour: Work and the Social Bond (Leiden, Brill, 2012) 63, 71.

${ }^{34}$ Kohler, 'Civic Virtue at Work' (n 28) 294-96.

35 ibid 295.

${ }^{36}$ P Levine, ‘The Legitimacy of Labor Unions’ (2001) 18 Hofstra Labor \& Employment Law Journal 529, 55960.

${ }^{37}$ K Polanyi, The Great Transformation: The Political and Economic Origins of Our Time (2 edn, Boston, Beacon Press, 2001) 1-2.

38 ibid 2.

39 ibid 75.

40 ibid 75.

${ }^{41}$ ibid 76.

${ }^{42}$ ibid.
} 
stripped down to its economic value, to be construed as merely a market commodity, despite the need for its economic function to be regulated to fit particular economic structures, the latest of which is the modern capitalist market ${ }^{43}$. There cannot be a market that exists outside and beyond specific social, political and legal institutions, which support the human web that constitutes the very fabric of the economy ${ }^{44}$.

Any effort to 'disembed' the economy from society will inevitably lead to strains that will, in turn, result in resistance. That is the essence of Polanyi's double movement thesis ${ }^{45}$ : dislocating the economy from its social context will undoubtedly result in social reaction ${ }^{46}$ to bring the economy and society back together.

Resistance, however, can take either of two forms: it can manifest as disorderly reaction via revolts and social unrest or, alternatively, it can be funnelled through pre-existing democratic institutions. Collective organisation is one such democratic hub that, by definition, exists to couple economic and social considerations and infuse democratic ethos in the labour market. In that respect, Polanyi meets Sinzheimer. The Polanyian objective of balance and re-connection of the economy to society through democratisation is served by the democratisation of the economy itself. That, according to Sinzheimer, is the ultimate goal of collective labour law and its institutions ${ }^{47}$.

It is this characteristic of the inherent interconnectivity of any economic system that regulates labour to social considerations and to the autonomy of the individual that informs the Hegelian idea of the necessity of an 'ethical basis' 48 of the economy, which operates as a moral anchor ${ }^{49}$. In other words, any economic system must take into account and cater for social considerations and relevant objectives, functioning as part of a coherent whole which encompasses the political, the social and the economic. In turn, by doing so, a socially embedded economic system can be accepted by its actors and thus be perceived as morally ${ }^{50}$, and therefore socially and politically, legitimate. This holistic picture of any te socioeconomic system resonates with the thesis of the fundamental socioeconomic duality of the function of collective labour law.

The social element of that duel character operates at both the individual and the collective level. Collective labour rights can be understood as a factor safeguarding individual autonomy, ensuring a dignified life and personal development. However, collective institutions are also critical in the formation of social identity and culture.

\footnotetext{
43 ibid 72-79.

${ }^{44}$ K Veitch, 'Law, Social Policy, and the Constitution of Markets and Profit Making' (2013) 40 Journal of Law and Society 137.

${ }^{45}$ See Polanyi, The Great Transformation (n 37) 136-40.

${ }^{46}$ ibid 156-57.

47 R Dukes, 'Constitutionalizing Employment Relations: Sinzheimer, Kahn-Freund, and the Role of Labour Law’ (2008) 35 Journal of Law and Society 341, 346; R Dukes, The Labour Constitution: The Enduring Idea of Labour Law (Oxford, Oxford University Press, 2014) 18-19.

${ }^{48}$ Smith and Deranty, New Philosophies of Labour (n 29) 17-18.

49 A Honneth, 'Work and Recognition: A Redefinition' in H-C Schmidt am Busch and C Zurn (eds), The Philosophy of Recognition: Historical and Contemporary Perspectives (Plymouth, Lexington Books, 2010) 229-30.

50 ibid 230; Smith and Deranty, New Philosophies of Labour (n 29) 17.
} 
In that respect, the working class, as the broad social cell through which a worker perceives her social identity and status, is not to be entirely economically construed, in the traditional Marxian fashion. It may start with the position one has within the market, but it might be better understood as a broader concept that encapsulates all aspects of social identity and experience, and involves a communion of not only overarching interests, but also of experiences, fundamental relation patterns, needs and consumption habits, community and political life 51 . In turn, in a world where globalisation of capitalism has not yet led to complete homogeneity, this working class experience, if not the perception of class itself, is influenced by the specific social and state structures, as well as by perceptions of different racial, ethnical, regional or even gender paradigms ${ }^{52}$. The result is often that the working class is initially constructed on the basis of fragmented consciousness formed by already existing prejudices and dividing lines.

This formational process through, and despite, pre-existing fragmentations was evident in the United States ('US') experience in the early days of the labour movement. In a land of extreme diversity, with cultural, ethnic or even religious lines clearly dividing the minds of workers, unions initially formed around those traditional societal divisions ${ }^{53}$. As a consequence, prejudice and antagonisms ensued ${ }^{54}$. However, over time what prevailed was the commonality of needs, experiences and industrial struggle, and the gradual emergence of a shared consciousness; a sense of belonging to a community, a class, on the basis of worker status, and not because of traditional divisions, but through them ${ }^{55}$. An illustrative example was the revolt of garment worker representatives in 1914, forged in the fire of unyielding strikes that had preceded it ${ }^{56}$, against the old establishment of union elites that had tried to maintain racial divides as a means of controlling the Union of Garment Workers (UGW) and the American Federation of Labor (AFL) ${ }^{57}$. The worker base demanded and eventually succeeded in bringing about change in the structure and ethos of the union itself, to reflect the sentiment it had voiced in the 1914 AFL convention: 'Let us unite in order to fight our

${ }^{51}$ E Arnesen, J Greene and B Laurie, Labor Histories: Class, Politics and the Working Class Experience (Chicago, University of Illinois Press, 1998) 4.

52 ibid.

${ }^{53}$ M Dubofsky and F Rhea Dulles, Labor in America: A History (8 edn, Wheeling, Harlan Davidson 2010 ) 72. See, for example, references in the creation of unions along national/ethnic lines (of Greeks, Italians and Mexicans) in GW Peck, 'Mobilizing Community: Migrant Workers and the Politics of Labor Mobility in the North American West, 1900-1920’ in E Arnesen, J Greene and B Laurie (eds), Labor Histories: Class, Politics and the Working Class Experience (Chicago, University of Illinois Press, 1998) 175-200; or racial lines (African American/white unions) in E Arnesen, 'Charting an Independent Course: African American Railroad Workers in the World War I Era' in E Arnesen, J Greene and B Laurie (eds), Labor Histories: Class, Politics and the Working Class Experience (Chicago, University of Illinois Press, 1998) 284-308.

${ }^{54}$ See Arnesen, 'Charting an Independent Course' (n 53) 296-302.

${ }^{55}$ An excellent example is revolt of the multinational force of Colorado Miners in 1913-1914, comprising workers of 21 nationality groups, led by Louis Tikas and resulting in the infamous Ludlow Massacre of 1914. See S Martelle, Blood passion: the Ludlow Massacre and class war in the American West (London, Rutgers, 2007); Z Papanikolas, Buried Unsung: Louis Tikas and the Ludlow Massacre (Salt Lake City, University of Utah Press, 1982); W Fink, The Ludlow massacre (New York, 1914).

${ }^{56} \mathrm{P}$ Foner, History of the Labor Movement in the United States Volume V: The AFL in the Progressive Era, 1910-1915 (New York, International Publishers, 1980) 226-56.

${ }^{57}$ ibid 260-64. 
common enemy, capitalism, instead of picking suicidal quarrels among ourselves'58. The socialising force that allowed for the transcendence of old lines of segregation and suspicion was the presence and operation of collective labour law institutions and the interaction and discourse they fostered.

However, commonality of interests and collective mobilisation can also transcend the traditional institutional structures of collective autonomy. It is useful to note that while these specific structures and mechanisms were put in place to organise collective mobilisation, they also had the effect of reigning in its force within specific preordained boundaries, including the scope of participation and coverage. Transcendence of those formal boundaries in practice, due to the substantive commonality of interests and of broader groups of de facto (but not necessarily de lege in any given legal order) workers signals the need of change as regards the institutional nexus of collective labour relations itself. An early institutionalist like John Commons, writing in 1913, while discussing the obstacles to the emergence of class consciousness among unionised workers in early $20^{\text {th }}$ century US, pointed to immigration and, therefore, racial, ethnic and religious tensions and ensuing antipathy, as a factor that would 'undermine'59 and, eventually, 'shatter' 60 class solidarity. Commons was of course referring to the oldest trick in the book: the use of immigrant workers as the scapegoat for the plight of the 'domestic' working class. By employing low-paid and non-unionised immigrant workers to circumvent established trade unions and their coercive mobilisation, employers also succeeded in aggravating racial and religious antipathies, effectively diverging workers' focus away from the commonalities of their status and experience that could incite class consciousness. The solution, according to Commons, was the prohibition or radical limitation of immigration ${ }^{61}$, rather than the integration of immigrant workers into existing communities and their collective labour institutions or, indeed, the transformation of those communal and institutional structures themselves under the effect and influence of their new members. Commons was desperate to see trade union structures, those newly formed institutions which had finally endowed disorganised labour with a structural framework, be allowed to breathe and function, without any external factor distorting the delicate balance upon which they had been built.

Institutions, however, are shaped, and can be transformed by the communal bonds that emerge out of necessity, as a result of common experience. These bonds are revealed through the raw social function of collective organisation, irrespective of whether this process is dominated by already established internal groups and union elites (as in the case of UGW and AFL) or whether it can even be made to fit pre-existing institutional frameworks.

Commons had already been proven wrong a few years before his assumptions about the obstacles to achieving class consciousness. The summer of 1909, in McKees Rock, Pennsylvania, saw the eruption of the steel workers strike against Press Steel Car Co and the

\footnotetext{
${ }^{58}$ CE Zaretz, The Amalgamated Clothing Workers of America: a Study in Progressive Trade-Unionism (New York, Ancon Publishing Company, 1934) 96.

59 J Commons, Labor and Administration (New York, MacMillan, 1913) 78.

60 ibid 79.

${ }^{61}$ ibid. cf Dubofsky and Rhea Dulles, Labor in America (n 53) 88, who point out that, of course, immigration was not really the determinant obstacle to the attainment of labour's goals.
} 
might of US Steel ${ }^{62}$. The company, one of the largest railroad cars manufacturers in the US, had embraced the tactic of employing immigrant labour (mostly of Slavic, East-European origin), subjected to appalling living conditions and inhumane abuse ${ }^{63}$ and, of course, devoid of institutional representation through established structures. The straw that broke the proverbial camel's back was a pay related grievance ${ }^{64}$. An ethnically diverse and unorganised workforce of 3,500 immigrant steel workers ${ }^{65}$ of sixteen different nationalities rose quickly to challenge not just the employer but also, and perhaps more importantly, the representatives of 'native' workers and their unions, who attempted to control the strike and steer the relevant negotiations. Though the unorganised immigrants initially achieved the rejection of agreements negotiated supposedly on their behalf that would amount to capitulation, ultimately they were overwhelmed by the 'native' representatives who dismissed 'the violence of the uneducated Slavs' and proceeded to reach a settlement with management, enforce the return to work, impose their established institutions and, patronisingly, create a night school program to 'educate’ immigrant workers on American institutions ${ }^{66}$.

It was clear that those who embraced established collective labour institutions at the time were sceptical and underprepared for ${ }^{67}$, if not completely averse to ${ }^{68}$, 'foreigners' who did not necessarily share their own societal and political perceptions, including as regards the role, function and objectives of collective mechanisms and their means of reaction. Nevertheless, McKees Rock proved that not only were 'unorganisable' immigrants perfectly capable of organising, but also that, through the shared experience with local workers, they were capable of inviting and inciting the support of their base, slowly building a community and common identity that would ultimately, and relatively quickly, come to inform and affect the institutional establishment over the following years and decades. In fact, by World War I new unions had emerged (such as the Amalgamated Clothing Workers of America (ACWA) in the garment and clothing sector) by achieving to organise the 'unorganisable' immigrants, but also by attracting women and ensuring that they would have equal status and role to their male colleagues ${ }^{69}$, irrevocably changing the formerly dominant trade union paradigm.

This important community and collective identity building function of collective labour institutions is often overlooked in mainstream discussion. As Clark argued, this function and the inter-community solidarity it fostered have been 'overwhelmed'70 by economic imperatives and financial objectives that transcend the traditional localised community and

\footnotetext{
62 JN Ingham, 'A Strike in the Progressive Era: McKees Rocks, 1909’ (1966) 90 The Pennsylvania Magazine of History and Biography 353; A Snyder, 'A Window of Solidarity in Steel: McKees Rocks, 1909' (2000) Honors Theses Paper 5, <https://knowledge.library.iup.edu/honors_theses/5/> accessed 20 December 2018.

${ }^{63}$ Ingham, 'A Strike in the Progressive Era' (n 62) 354-55; Snyder, 'A Window of Solidarity in Steel' (n 62) 6-8.

${ }^{64}$ Snyder, 'A Window of Solidarity in Steel' (n 62) 359.

65 ibid 371.

${ }^{66}$ ibid 372.

${ }^{67}$ B Ramirez, When Workers Fight: the Politics of Industrial Relations in the Progressive Era, 1898-1916 (Connecticut, Greenwod Press, 1978) 136-37.

${ }^{68}$ Ingham, 'A Strike in the Progressive Era' (n 62) 376-77.

${ }^{69}$ Dubofsky and Rhea Dulles, Labor in America (n 53) 188.

${ }^{70}$ G Clark, Unions and Communities under Siege: American Communities and the Crisis of Organized Labor (Cambridge, Cambridge University Press, 1989) ix.
} 
have ascended to become the absolute priority. Throughout his work looking into the history of organised labour in the Cold War period (1950s-1989) $)^{71}$, Clark demonstrated and emphasised the absolute interconnectivity between specific communities and their local conditions, unions, and collective labour institutions. What Clark uncovered was that the rise, life, and decline of unionism cannot be disassociated from its spatial context, that is, from the particular characteristics and divides that define the community in which union structures emerge and which unionism serves.

As a result, even the often cited problems of representativeness and membership decline that have plagued trade unions in recent decades in the US, but, also, arguably, throughout the Western world, should not merely be attributed to a the supposed adverse effect union structures have on economic efficiency and, thus, on the economy as a whole, which leads to reduced profits and, thereby, reduced returns for workers and employers alike. On the contrary, a more thoughtful and holistic approach could reveal the effect geographical divides $^{72}$ and local interests can have on any attempt to form a single collective voice capable of expressing the interests of unionised, yet geographically fragmented, workers. However Lash and Urry's 'disorganised' capitalism is also 'dislocated': globalised and inherently fluid and mobile. Corporate strategies transcend local and national boundaries, as does the capability of transnational capital to weather, if not completely nullify, the presumed adverse effects (not merely the purely economic cost) ${ }^{73}$ that collective worker mobilisation can have, by simply relocating ${ }^{74}$ its operations. This inherent capacity of capital and production mobility can disjoint unionisation from its spatial and specific social context, making it harder for the necessary community bonds to emerge and give rise to credible union structures as their institutional vehicle and voice. This mobility, then, could present one plausible explanation for the decline in union density and membership in recent years.

Overall, failing to understand the complex social communal character of collective labour institutions leads to a monolithic, one-dimensional approach towards them that misses the complexity of their functions and objectives ${ }^{75}$. In turn, this approach leads to the marginalisation of another process that builds on social bonds and re-organises them into forms and institutions that facilitate the constitution of a community into a particular political system which prioritises this sense of commonality: democracy.

\section{B. Collective Labour Rights as the Vehicle of Market Democratisation}

What labour law analyses often tend to forget is that the mere existence of labour law institutions, especially those related to collective autonomy, is the product of intense political struggle that was not conceived as narrowly as the contractual context that usually constitutes the basis of legal interpretation. Collective labour law was born out of the sweat and blood of massive movements demanding not merely bargaining equality, but dignity, control of the tyrannical paradigm of the employer as absolute sovereign and, ultimately, a share in the

\footnotetext{
71 ibid.

72 ibid 40.

73 ibid 53-56.

74 ibid 45-66.

75 ibid 40.
} 
power to determine the norms and orders imposed on them ${ }^{76}$. In other words, the labour movement that pushed the state and the courts to create the set of principles and statutory norms that would effectively create a new field of law (today taken for granted), was analogous in its fundamental aspirations and development to the popular and political movements that dragged the western world out of the systemic middle ages of monarchy, feudalism and aristocracy, into the modern era of liberal western democracy.

It is important to recall that both these movements were not so much, if at all, concerned with the economic characteristics of the market or the effects of regulation on its structure and perceived qualities. The focus was on countering autocratic control of the lives of workers and citizens respectively by demanding the exercise of authority through democratic processes and respect of fundamental rights. Workers did not see themselves as merely elements of an economic framework(and a relevant normative structure that was to be taken for granted and in isolation from its context), but as societal and political actors as well. And although early movements could not necessarily articulate what exactly their demand for 'democracy in the industry' entailed, they had a gut feeling that such a demand was not only natural, but indeed patriotic ${ }^{77}$, the logical extension of their civic duties and entitlements and the normal corollary of a democratic polity.

Indeed, as Lichtenstein and Harris remark, the term 'industrial democracy' 78 in the US, at its initial conception and emergence, was practically understood to mean something broader than mere collective bargaining. It was construed to signal the penetration of democratic principles and values into production processes and industry, and to indicate that 'industry', or the labour market, should conform to the democratic character of the political culture and systemic and constitutional framework that constitute its context ${ }^{79}$.

Consequently, the demand for the creation of labour standards and institutions was ultimately a demand for democratisation and systemic fairness. Its realisation unfolded through conflict and concessions at the social and political level, that went beyond industry or the labour market and engulfed national politics ${ }^{80}$, before the outcomes became mantled in legal theories and arguments and transposed into legal norms.

a. Workplace Democratisation

Some early collectivist constructions of the phrase 'industrial democracy' in the US, adopted by activists ${ }^{81}$ and certain workers' factions, effectively implied collective ownership of the

\footnotetext{
${ }^{76}$ Indicatively, for an overview of the US example, and the political characteristics and variety of demands and objectives relating to worker struggles therein, see Ramirez, When Workers Fight (n 67).

${ }^{77}$ McCartin, Labor's Great War (n 32) 1, 7.

${ }^{78}$ See also D Milton, The American Idea of Industrial Democracy, 1865-1965 (Chicago, University of Illinois Press, 1970).

${ }^{79} \mathrm{~N}$ Lichtenstein and HJ Harris, Industrial Democracy in America: The Ambiguous Promise (Cambridge, Cambridge University Press, 1993) 2.

${ }^{80}$ McCartin, Labor's Great War (n 32) 4-5. McCartin's book is a wonderful account of precisely the interplay between worker movements and industrial demands, on the one hand, and national politics (including multiple complex considerations, from foreign policy and conducting war to dealing with immigration and combating social divisions).

${ }^{81}$ HD Lloyd, Men, The Workers (New York, Doubleday, 1909) 91.
} 
means of production and collectivisation of industry ${ }^{82}$. Conditions of employment and the division of profits ought to be determined by workers themselves; work supervisors ought to be chosen by workers to serve them, and work and production itself should be organised so as to benefit the collective, ensuring equality for all participant labourers ${ }^{83}$.

More conservative American trade unionists of the time, however, espousing a form of 'working-class republicanism' 84 that did not wish for radical departures from the established systemic status quo ${ }^{85}$, adopted a more modest definition. For them, democratising industry simply was the natural extension of citizenship ${ }^{86}$, and the fundamental principles and (civil and political) rights it entails, so as to manifest in the context of the market ${ }^{87}$. The relevant unit of potential conflict (establishment; company; sector; industry) ought to be organised in accordance with the principles that govern the relationship between the state and individuals, including the guarantee of fundamental rights and mechanisms that would prevent abuse of power by the dominant authority (in this case, the employer, as analogous to the state). This form of 'industrial citizenship' would be funnelled through specific institutions and mechanisms, with trade unions at their core. That is precisely why, as Clark notes, not just formal electoral processes but, more importantly, electoral politics, were transplanted into collective labour institutions in the US straight from the political sphere ${ }^{88}$.

Analysing the conditions and developments in the UK at the time, Sidney and Beatrice Webb seemed to share the broad tenets of 'working class republicanism' as opposed to ideas of collectivisation of production. The observations, arguments and theories they developed in 1898 under the moniker 'Industrial Democracy' ${ }^{89}$ also considered the paradigm of the liberal democratic state as the basis for their examination of the internal workings of trade unions and their counterbalancing role vis-a-vis the dominant authority of the employer. They remarked: 'trade unions are democracies: that is to say, their internal constitutions are all based on the principle of "government of the people by the people for the people", 90 .

Ultimately, that same paradigm is what Kahn-Freund adopted as the basis for his analysis. For Kahn-Freund, the workplace micro-polity is not to be necessarily organised on the basis of direct democracy, as a commune or a collective. To use his own words, workplace

\footnotetext{
${ }^{82}$ Lichtenstein and Harris, Industrial Democracy in America (n 79) 4.

${ }^{83}$ Lloyd, Men, The Workers (n 81).

${ }^{84}$ Lichtenstein and Harris, Industrial Democracy in America (n 79) 3-4.

${ }^{85}$ D Montgomery, 'Industrial Democracy or Democracy in Industry?: The Theory and Practice of the Labor Movement 1870-1925' in N Lichtenstein and HJ Harris (eds), Industrial Democracy in America: The Ambiguous Promise (Cambridge, Cambridge University Press, 1993) 41-42. cf HJ Harris, 'Industrial Democracy and Liberal Capitalism' in N Lichtenstein and HJ Harris (eds), Industrial Democracy in America: The Ambiguous Promise (Cambridge, Cambridge University Press, 1993) 46, noting that the fallacy of the working-class republicanism position is that it disregards the orthodox liberal position that separates between the public and private sphere. As the employment relationship is based on economic freedom, encompassing freedom of contract, it sits firmly within the private sphere, and, therefore, transpositions of public sphere arguments, principles and mechanisms is inappropriate.

${ }^{86}$ Montgomery, 'Industrial Democracy or Democracy in Industry?' (n 85) 25.

${ }^{87}$ Lichtenstein and Harris, Industrial Democracy in America (n 79) 4.

${ }^{88}$ Clark, Unions and Communities under Siege (n 70) 37. See also 91-109.

${ }^{89}$ S Webb and B Webb, Industrial Democracy (2 edn, London, Longmans, Green and Co, 1902).

90 ibid v-vi.
} 
democracy simply means 'that those who have to obey the rules have an active share in making them, and this is true of political as well as of "industrial" democracy" ${ }^{91}$. Therefore, democratisation of the workplace, and hence the market, does not inherently refute the dominant decision-making position of the employer, nor does it entail the nullification of employers' economic freedom. It simply denotes participation in the making of workplace rules through representative agents ${ }^{92}$, and not necessarily absolute codetermination or collective self-administration

Thus, the more modest model that early US 'working class republicans', UK Institutionalists and traditional scholars such as Kahn-Freund had in mind does not contradict traditional liberal theory and its inherent respect for individual autonomy and economic freedom. In fact, it is entirely compatible with that tradition ${ }^{93}$, and therefore with capitalism and the modern version of the labour market. That said, if we are to accept this balanced liberal interpretation, all the features and virtues of the liberal representative polity paradigm are to be transplanted to the workplace ${ }^{94}$ : from respect for individual rights, to the democratic processes by which the collective voice of all 'industrial citizens', majority and minority included, is to be expressed by their elected representatives, so as to influence the construction of the norms that affect them. Therefore, not only can collective worker processes and institutions be judged using democracy and democratic theory as a standard, but they constitute a concrete manifestation of democracy and the political method it entails ${ }^{95}$. In fact, the inherent interconnectivity of the social and democratic function of (particularly local) collective labour institutions suggests that they are best suited to act as a primary hub of democracy and democratic expression, due to the immediateness of their processes to their spatial and social context, and to the relationships, particular characteristics and issues that characterise it ${ }^{96}$. Democratic standards and theory apply to both internal trade union democratic procedures and the 'external' process of collective bargaining.

The mechanism of workplace democracy culminates in setting, through collective agreements, norms that ultimately constitute the 'negotiated law' ${ }^{97}$ which governs the workplace micro-polity. Collective agreements often go beyond just configuring working conditions. They also establish mechanisms and processes for the resolution of conflict and for providing a fair hearing before the imposition of penalties. Disciplinary and grievance procedures constitute the internal 'judicial' processes of the workplace that ensure accountability and transparency, but also respect for individual rights. This illustrates that

\footnotetext{
${ }^{91}$ P Davies and M Freedland, Kahn-Freund's Labour and the Law (3 edn, London, Stevens, 1983) 23. 92 ibid.

93 See H Collins, 'Theories of Rights as Justifications for Labour Law' in G Davidov and B Langille (eds), Boundaries and Frontiers of Labour Law (Oxford, Hart, 2006) 144-46.

${ }^{94} \mathrm{H}$ Arthurs, 'Landscape and Memory: Labour Law, Legal Pluralism and Globalisation' in T Wilthagen (ed), Advancing Theory in Labour law and Industrial Relations in a Global Context (Amsterdam, North-Holland, 1998) 27-28.

95 J Barbash, Labor's Grass Roots: A Study of the Local Union (Westport, Greenwood Press Publishers, 1974) 215-16.

96 ibid 240.

${ }^{97}$ A Supiot, Homo Juridicus: On the Anthropological Function of the Law (S Brown tr, London, Verso, 2007) 162.
} 
collective labour law is the means that guarantees that the workplace mini-polity ${ }^{98}$, as a system of 'industrial self-government' ${ }^{99}$, does not merely produce 'negotiated law', but is actually 'governed by an agreed upon rule of law, 100 .

Furthermore, the idea that those who are affected by employment related decisions, norms and conditions are entitled to participate in the regulation of labour, connects with deeper, substantive (rather than merely procedural) democratic themes. Freedom from coercion, the need to scrutinise the exercise of power, and the avoidance or peaceful resolution of conflict $^{101}$, are all linked to the idea of participation, and, therefore, the expression of collective voice $^{102}$. These objectives are relevant to the workplace context but also, more broadly, crucial for any political community. They constitute rights and expressions of individual freedom ${ }^{103}$ for the person in her capacities as both a worker and a citizen. In essence, collective labour institutions are the conduits through which the rule of law is established in the workplace ${ }^{104}$, to curtail the absolute sovereignty of the employer.

Collective labour institutions, therefore, are not merely precursors of conflict and clashes of interest between labour and management. As with any democratic system of governance, their main objective is to promote reconciliation and consensus through mutual concessions and respect of individualism, and to achieve an agreeable balance and peaceful coexistence to the benefit of the whole. Consequently, their existence and effective operation is not antithetical to the unfettered functioning of a free market economy; it is imperative for its balance and stability. Further still, democratising the workplace can ultimately result in the democratisation of the market itself.

Economic analyses of the function of collective labour law, no matter how 'labourfriendly', unavoidably accept the centrality of economic arguments, regardless of the particular school of economic thought they might be derived from. Inherently, therefore, they construe the modern systemic structure of capitalism as a given, seeking only to restrain its effects. By adopting this premise and the theoretical tools it restricts them to, economic approaches inadvertently adopt the fundamental reasoning of the system they seek to restrain, albeit attempting to use it to the benefit of workers. What is ultimately adopted is the basic tenet of the self-regulated market; what is sought is simply an alternate path to selfregulation.

Instead, the real need is to do away with the neoclassical fallacy of the autonomous operation of markets and place them within the social, constitutional and legal environment in which they operate, subduing market forces to the collective choices made by the people the economic system is meant to serve ${ }^{105}$. The democratisation of the market is but a facet of systemic democratisation.

\footnotetext{
${ }^{98}$ See Webb and Webb, Industrial Democracy (n 89) 808.

99 Steelworkers v. American Mfg. Co., No 363, $363 \quad$ U.S. $564 \quad$ (1960), $570 \quad$ (see $<$ https://supreme.justia.com/cases/federal/us/363/564/case.html> last accessed 20 December 2018).

${ }^{100}$ Kohler, 'Civic Virtue at Work' (n 28) 298.

${ }^{101}$ Davies and Freedland, Kahn-Freund's Labour and the Law (n 91) 27.

102 R Freeman and J Medoff, What Do Unions Do? (New York, Basic Books, 1984) 7-11.

${ }^{103}$ Dukes, The Labour Constitution (n 47) 30-1.

${ }^{104}$ Kohler, 'Civic Virtue at Work' (n 34); McCartin, Labor's Great War (n 32) 95.

${ }^{105}$ cf McCartin, Labor's Great War (n 32) 206-207.
} 


\section{b. Systemic Democratisation}

The democratisation of the market is systemically connected with the democratisation of the society within which the market operates ${ }^{106}$. Substantive market democratisation contributes to the overall perception of the legal superstructure as being democratically legitimate, emerging from popular participation and resulting in collective benefit ${ }^{107}$. Any discussion of a democratically regulated polity cannot be insulated from an examination of the degree to which its economic system complies in practice with that polity's fundamental standards of democratic functioning. Equally, any economic system and its inherent processes and institutions cannot be examined without reference to their systemic democratic legal and political context. This highlights the importance of considering, in any analysis, the function and role of labour law ${ }^{108}$ and of collective labour mechanisms as its 'democratisation tools'.

Undoubtedly, the economic and social effects that collective organisation produces for individuals can positively impact upon structural systemic democratisation and the promotion of an ethos of participation. Furthermore, substantively, participation in collective labour law structures can benefit the quality of democracy ${ }^{109}$, building upon and going beyond the economic emancipation of workers.

At a basic level, and corollary to the economic function and objective of collective labour law, collective organisation in pursuit of the protection of the narrow economic interests of workers within the workplace can result in their personal and political emancipation. A worker given the chance to participate in the regulation and organisation of her own working conditions and the provision of her labour, and thus to have her own economic freedom fully respected, develops into a citizen that demands and enjoys greater freedom from coercion. Stability and relative economic security allow for greater liberty of choice. Moreover, as we have seen, that sense of commonality facilitates the transcendence of racial, gender or ethnic prejudices, and the forging of an inclusive social consciousness and identity. An individual forged in collective organisation and a sense of commonality, on a primary level deployed as a means to escape abuse and subordination from her direct economic superior, the employer, can employ these learned tools to safeguard her community against abuse from any overbearing group or institution.

Therefore, beyond the narrow confines of workplace democratisation, collective organisation can operate as a vehicle for the exertion of political pressure towards central political actors on issues relevant to worker interests, including those pertaining to the regulation of the labour market, and the consequent interventions of state institutions ${ }^{110}$.

\footnotetext{
106 See Webb and Webb, Industrial Democracy (n 89) 842. See also Lichtenstein and Harris, Industrial Democracy in America (n 79) for an account of this parallel process in the US context.

107 See Smith and Deranty, New Philosophies of Labour (n 29) 21; Honneth, 'Work and Recognition: A Redefinition' (n 49) 223.

108 See Smith and Deranty, New Philosophies of Labour (n 29) 22-23.

${ }^{109} c f$ the relevant point, though more based on a predominantly economic understanding of modern democracy, in J Atleson, Values and Assumptions of American Labor Law (Amherst, MA, University of Massachusetts Press, 1983) 35-43.

${ }^{110}$ G Lester, 'Beyond Collective Bargaining: Modern Unions as Agents of Social Solidarity' in G Davidov and B Langille (eds), Boundaries and Frontiers of Labour Law (Oxford, Hart, 2006) 331. cf Levine, 'The Legitimacy of Labor Unions' (n 36) 562-67.
} 
The political value of collective organisation and action cannot be overstated. The labour movement, as a precursor to legal and normative change, cannot be separated from the realm of politics; nor can its historical examination ${ }^{111}$ or theoretical framing. On the contrary, this movement has always been interwoven with the political process, itself an expression of civic rights and a manifestation of the social forces that drive political developments, which, ultimately, legitimise and transpose to the legal realm social, political and economic change ${ }^{112}$. And if we consider trade unions, or any such collective institution, as a primary hub of politicisation and a Petri dish of micro-democracy, then to understand the effect of the worker movement on politics and, consequently, the broader reality and true nature of a particular polity, we also need to examine their inner workings and culture ${ }^{113}$. As much as the accounts of worker mobilisation and the labour movement as a whole help us to reconnect with the roots of the normative concepts that form labour law's analytical tools, so too does examining the 'internal' history of trade unionism, so as to understand the effects that participation in collective processes can have on workers as individuals.

At the same time, through their participation in the collective institutions that allow for the promotion of their economic interests, workers develop their bourgeois identity. They develop their sense of belonging to a commonality of interests, while concurrently realising that those interests can be better promoted through dialogue and mutual concessions with those of opposing objectives. In other words, besides the ethos of participation, workers develop the deeper, substantive, democratic reflexes and 'skills ${ }^{114}$, as well as the relevant experience, that allows for quality debate, deliberation and balancing of opposing views ${ }^{115}$.

Thus, workers are schooled ${ }^{116}$ in the prerequisites of effective, respectful engagement in the public sphere and democratic processes. This is not merely an abstract process. It can entail, and has taken the form of, a practical pedagogical aspect ${ }^{117}$. Trade unions in the past have actively engaged in educating workers, not only in the technical skills and processes related to collective bargaining and lobbying (such as communication, negotiation, dealing with financial information and engaging with state institutions), but also in the social, democratic, political, and, ultimately, systemic context of collective labour processes. Using trade unions as actual 'schools' - mechanisms to ensure the education of the working class had been suggested in post-World War II UK, not only as a means of enhancing trade unionism as such, but also as a tool that could help improve industrial efficiency and the

\footnotetext{
${ }^{111}$ A Fox, History and Heritage: Social Origins of the British Industrial Relations (London, Allen \& Unwin, 1985) xii.

112 J McIlroy, A Campbell and N Fishman, ‘Approaching Post-War Trade Unionism’ in J McIlroy, A Campbell and N Fishman (eds), British Trade Unions and Industrial Politics: The Post Was Compromise, 1945-1964 (Aldershot, Ashgate Publishing, 1999) 10.

113 D Marsh, The New Politics of British Trade Unionism: Union Power and the Thatcher Legacy (Ithaca, ILR Press, 1992).

${ }^{114}$ Levine, 'The Legitimacy of Labor Unions' (n 36) 561-62.

115 ibid 567-569; Kohler, 'Civic Virtue at Work' (n 28) 300.

${ }^{116}$ Kohler, 'Civic Virtue at Work' (n 28) 299.

117 J McIlroy, 'Making Trade Unionists: The Politics of Pedagogy, 1945-79' in J McIlroy, A Campbell and N Fishman (eds), British Trade Unions and Industrial Politics: The Post Was Compromise, 1945-1964 (Aldershot, Ashgate Publis'hing, 1999) 37-65.
} 
quality of systemic participatory democratic processes, essentially creating a better educated, more informed and, thereby, more mature populace ${ }^{118}$.

McIlroy charts unions' gradual transition from attempts to ensure such broad emancipatory education, to eventually providing much narrower and more superficial 'industrial relations training' ${ }^{119}$. He argues that reducing the scope of the education to just the technical skills required to deal with the specific established contemporary framework of industrial relations essentially implied capitulation on the part of labour, embracing not only that particular institutional framework ${ }^{120}$, but also its ideological and conceptual premises. Workers might still recognise the disparity of interests between management and labour, but they essentially agreed to and affirmed an idea of what balance between those interests might entail ${ }^{121}$. More importantly, however, McIlroy's analysis and arguments suggest that, to an extent, we can trace the seeds of resignation to the inevitability of contemporary free market structures and neoliberal tenets to the dilution of workers' education. Unconsciously embracing the established framework, workers and unions often struggle to perceive broader political and economic implications or possibilities ${ }^{122}$, and to engage in transformative practices akin to those that produced by what we understand today as 'labour law'.

In summary then, and regardless of the demise of actual education schemes, even the mere act of participation in collective organisation helps individual workers realise the commonality of interests among them and the value of solidaristic structures and cooperation. Moreover, it opens them to the experience of collective, and consequently political, processes, and it helps them forge a solid understanding of the broader socioeconomic and political context, and the interplay between the various state and non-state actors engaged in it. In other words, trade unions and collective labour law mechanisms become incubators of civic virtues ${ }^{123}$. They forge workers in their micro-democracies, so as to evolve, in turn, into conscious, engaged citizens within the greater polity.

This was certainly the effect of early labour movements in the $19^{\text {th }}$ and $20^{\text {th }}$ century, which cannot be disconnected from their political character. The result of that interplay was also tangible in the political awakening and subsequent active engagement of workers ${ }^{124}$, ultimately leading to the adoption of progressive policies and the strengthening of protective social regulation, but also to the enhancement of social inclusion and social equality in all forms ${ }^{125}$. It is certainly not coincidental that unionisation is related to the civil and political

\footnotetext{
118 ibid 38.

119 ibid 42-59.

${ }^{120}$ ibid 56-57.

121 ibid 47.

122 ibid 59.

${ }^{123}$ Kohler, 'Civic Virtue at Work' (n 28) 279-304.

${ }^{124}$ Inter alia see C Bucki, 'The Worker's State: Municipal Policy, Class and Taxes in the Early Depression' in E Arnesen, J Greene and B Laurie (eds), Labor Histories: Class, Politics and the Working Class Experience (Chicago, University of Illinois Press, 1998) 124-49. cf McCartin, Labor's Great War (n 32).

${ }^{125}$ See, for example, the link Kahlenberg and Marvit identify between collective worker organising and the objectives of human dignity and equality, particularly as regards people of colour, of the Civil Rights Act in the US in R Kahlenberg and M Marvit, Why Labor Organizing Should Be A Civil Right (New York, The Century Foundation Press, 2012) 89-101.
} 
right of association under Art.11 ECHR, with its caveats, or why it is argued that it should be fully recognised and protected, including the corollary right to strike, as a civil right in the sense of the American legal and political tradition of those rights as expressed in the US Civil Rights Act ${ }^{126}$.

\section{Systemic Democratisation: Overcoming Contemporary Boundaries}

The analogies to be drawn from the US experience of the early $20^{\text {th }}$ century illustrate the integrative effect of worker participation in the struggle to democratise the market as a preamble to systemic democratisation. More importantly, however, they indicate the potential for social and political emancipation, and the emergence of a common consciousness that defies boundaries, either those based on the traditional narrow scope of worker interests as confined to workers alone, or those that restrain their expression within certain geographic or national bounds.

Conscious of the social interconnectivity of interests, modern trade unions often break the boundaries that delimit their traditional function to be within the workplace or the confines of the labour market, to connect with their broader communities ${ }^{127}$ in pursuit of wider social objectives $^{128}$. More recent examples of trade unions engaging in community wide local initiatives to push for social policy reforms ${ }^{129}$, or leading social movements, such as that against water privatisation in Greece during the Eurozone crisis, illustrate the capacity of collective structures to open up to the greater society, and function as hubs of social and political mobilisation ${ }^{130}$. Therefore, reality appears to disprove Rawlsean interpretations by which trade unions are judged to be inherently undemocratic, because their core objective is to induce wealth redistribution for the promotion solely of the interests of the closed caste of their members ${ }^{131}$.

On a greater scale, forms of transnational cooperation between national trade unions have increasingly been challenging market globalisation by approaching common problems (not solely related to labour, but also to democratic, social and ecological considerations ${ }^{132}$ ) from an international perspective ${ }^{133}$. These transnational collective cooperation webs provide an invaluable means for ensuring that the voice of workers can be heard in an environment which has developed into a space virtually free of the democratic intervention, accountability and control traditionally exercised through state structures.

As the Brexit vote and the result of the 2016 presidential elections in the US perhaps indicate, we may have reached the point where the first cracks are appearing to the inevitability of the free market dogma in its neoliberal form, with its aversion to the perceived

\footnotetext{
126 ibid.

${ }^{127}$ KVW Stone and S Cummings, 'Labour Activism in Local Politics: From CBAs to 'CBAs'” in G Davidov and B Langille (eds), Boundaries and Frontiers of Labour Law (Oxford, Hart, 2006) 273-92.

${ }^{128}$ Munck, 'Labour Dilemmas and Labour Futures' (n 12) 15; Supiot, Beyond Employment (n 8) 132.

${ }^{129}$ Stone and Cummings, 'Labour Activism in Local Politics' (n 127).

${ }^{130}$ cf P Waterman, 'The New Social Unionism: A New Union Model for a New World Order' in R Munck and P Waterman (eds), Labour Dilemmas and Labour Futures (Oxford, Palgrave MacMillan, 1999) 260-61.

${ }^{131}$ See Levine, 'The Legitimacy of Labor Unions' (n 36) 536.

132 cf Waterman, 'The New Social Unionism' (n 130) 256-57.

133 Munck, 'Labour Dilemmas and Labour Futures' (n 12) 15.
} 
'obstacles' that democratic processes erect to market flexibility. As public trust in the institutions and functions of both the market and the state wanes in the post-Thatcherite neoliberal globalised world, recalling the galvanising and catalytic effects of market democratisation in the previous major crisis of capitalism might be useful.

\section{Conclusions: Rediscovering the Multiple Constitutive Value of Collective Labour law in a Contemporary Context}

The origins and inherently complex functions of collective labour institutions and processes reveal their multidimensional value. Precisely due to their complex economic and sociopolitical nature and role, collective labour institutions can play a constitutive role, helping shape new identities, social structures and political ideas from the bottom up, leading to renewed systemic consensus.

Ruth Dukes's compelling work ${ }^{134}$ brought into light Hugo Sinzheimer's conviction that collective labour law is a catalyst to bring about the constitutionalisation and democratisation of the economy. For Sinzheimer, collective labour processes and state institutions are symbiotic, feeding from each other and affecting one another ${ }^{135}$. Collective autonomy, according to his model, uses state created institutional structures, including the legal framework, to affect the economic sphere. However, through its multiple functions, it helps shape and promote broader systemic normative objectives, including the pursuit and protection of individual autonomy and freedom, hence improving the quality of systemic democracy.

In that respect, labour law, and collective labour institutions, should not be regarded purely through a traditional lens which considers them 'private law' ${ }^{, 136}$ stemming out of contractual freedom and the self-regulating capacity of the market. On the contrary, they better resemble elements of public law; they are, in essence, applied constitutional law, subjugating the economic realm to the normative will of the democratic, political constitution ${ }^{137}$. In that respect, state intervention to facilitate the constitutionally prescribed balance is welcome ${ }^{138}$. Consequently, collective labour institutions emerge as an instrument of Razian 'common ideology'. They are part of a coherent, pluralistic whole, which includes economic structures and interests as elements of the overall polity ${ }^{139}$, as means to the ends of the common constitutional good, including social coherence, democracy and social justice ${ }^{140}$.

Moreover, collective labour processes can go deeper than merely facilitating superfluous democratic participation, reach the heart of qualitative democracy and social cohesion: the

\footnotetext{
${ }^{134}$ Dukes, The Labour Constitution (n 47).

135 ibid 69-91; Dukes, 'Constitutionalizing Employment Relations' (n 47) 344, 356-60.

${ }^{136}$ Dukes, The Labour Constitution (n 47) 31; cf Dukes, 'Constitutionalizing Employment Relations' (n 47) 36061 on Kahn-Freund.

${ }^{137}$ Dukes, The Labour Constitution (n 47); and Dukes, 'Constitutionalizing Employment Relations' (n 47).

${ }^{138}$ cf Kahn-Freud's disagreement illustrated in Dukes, 'Constitutionalizing Employment Relations' (n 47) 34344.

${ }^{139}$ Dukes, The Labour Constitution (n 47) 31.

${ }^{140}$ cf ibid 66-67.
} 
rediscovery of a broader sense of belonging and solidarity ${ }^{141}$. The first step towards that is the realisation of worker individual, class and bourgeois identity. Unquestionably the socialising, democratising and emancipating effects of collective labour law processes shape workers' self-awareness and identity as individuals and bourgeois citizens. Through these processes workers are reconnected with a sense of belonging to a particular class, but also to a particular community.

Supiot has argued that, as an aspect of the shake-up of market structures, labour mobility and the 'flexibility' of employment forms have disrupted and reshaped the largely homogenous $^{142}$ (at least in terms of nationality, gender and cultural background) labour force $^{143}$. This is suggested to have led to disarray in familiar patterns of self-identification with an easily defined working class ${ }^{144}$. Realisation of that common identity is necessary for the emergence of the sense of commonality that underlines solidarity and its institutional manifestations, in the form of participation in collective labour structures and systemic democratic processes. Re-constructing this thread of a realised common fate, which is ultimately what connects the members of any constitutive demos as citizens of a shared polity, is imperative. The urgency of this becomes clearer once we consider the emerging dangers of extremist populism, that which comes with disillusionment and disenfranchisement in the absence or loss of that connecting thread of commonality and the tools to express it.

It is therefore no coincidence that, in the US context, suggestions have been made to reframe the freedom to associate in collective labour law institutions as a civil right ${ }^{145}$. Kahlenberg and Marvit, for example, look beyond the confines of the market role of trade unions, and even their function as schools of the democratic process, incubators of political ideas or emancipatory mechanisms. To Kahlenberg and Marvit, the right to organise and participate in collective action is a means of ensuring a dignified existence. Therefore, it shares the fundamental objective of the civil rights movement: that all people should be treated with decency ${ }^{146}$.

Collective labour law institutions ought to be perceived beyond their 'market regulation' shackles of economic thinking, in order for their multiple functions to bear fruit. Freedom of association and collective action, in any form and in relation to any aspect of socio-political and socioeconomic life, are fundamental prerequisites of a functioning democratic society. They are designed to infuse the market with democratic principles, but also to ensure the diffusion of checks and balances that ensure protection from abuse, exploitation and inequality and a dignified life, beyond the state governmental context, to extend to every institution that operates within a certain polity.

\footnotetext{
${ }^{141}$ G Monbiot, Out of the Wreckage: A New Politics for an Age of Crisis (London, Verso, 2018) 71-92.

142 Supiot, Beyond Employment (n 8) 25

143 ibid 94.

${ }^{144}$ Lash and Urry, The End of Organised Capitalism (n 19) 283-84.

${ }^{145}$ Kahlenberg and Marvit, Why Labor Organizing Should Be A Civil Right (n 125).

146 ibid 12.
} 
B1.Vergis / 11376 words

The tools to accommodate this shift in our perception of collective labour law are there; we do not need to reinvent them. We merely need to recover them from the dusty corners of history, where we left them.

All this has happened before. 